\title{
Effects of Oxygen and Catalyst on Tetraphenylborate Decomposition Rate
}

by

\author{
D. D. Walker
}

Westinghouse Savannah River Company

Savannah River Site

Aiken, South Carolina 29808

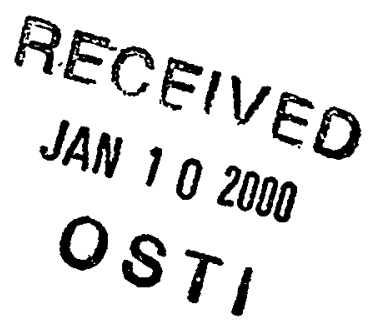

This paper was prepared in connection with work done under the above contract number with the U.S.

Department of Energy. By acceptance of this paper, the publisher and/or recipient acknowledges the U.S. Government's right to retain a nonexclusive, royalty-free license in and to any copyright covering this paper, along with the right to reproduce and to authorize others to reproduce all or part of the copyrighted paper. 


\section{DISCLAIMER}

This report was prepared as an account of work sponsored by an agency of the United States Government. Neither the United States Government nor any agency thereof, nor any of their employees, makes any warranty, express or implied, or assumes any legal liability or responsibility for the accuracy, completeness, or usefulness of any information, apparatus, product or process disclosed, or represents that its use would not infringe privately owned rights. Reference herein to any specific commercial product, process or service by trade name, trademark, manufacturer, or otherwise does not necessarily constitute or imply its endorsement, recommendation, or favoring by the United States Government or any agency thereof. The views and opinions of authors expressed herein do not necessarily state or reflect those of the United States Government or any agency thereof.

This report has been reproduced directly from the best available copy.

Available for sale to the public, in paper, from: U.S. Department of Commerce, National Technical Information Service, 5285 Port Royal Road, Springfield, VA 22161

phone: (800) 553-6847

fax: (703) 605-6900

email: orders@ntis.fedworld.gov

online ordering: http://www.ntis.gov/ordering.htm

Available electronically at http://www.doe.gov/bridge

Available for a processing fee to U.S. Department of Energy and its contractors, in paper, from: U.S. Department of Energy, Office of Scientific and Technical Information, P.O. Box 62, Oak Ridge, TN 37831-0062

phone: (865)576-8401

fax: (865)576-5728

email: reports@adonis.osti.gov 


\section{DISCLAIMER}

Portions of this document may be illegible in electronic image products. Images are produced from the best available original document. 
WSRC-TR-99-00279, Rev. 0

Keywords: Salt alternatives, Palladium, Platinum, Benzene

Retention: Permanent

\section{EFFECTS OF OXYGEN AND CATALYST ON TETRAPHENYLBORATE DECOMPOSITION RATE}

D. D. Walker

Publication Date: September 7, 1999

Westinghouse Savannah River Company

Savannah River Technology Center

Aiken, SC 29808

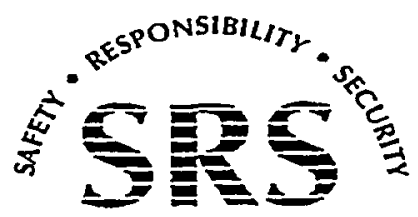

SAVANNAH RIVER SITE 
WSRC-TR-99-00279, Rev. 0

Page 2 of 17

Effects of Oxygen and Catalyst on Tetraphenylborate Decomposition Rate

Author

$$
=
$$

Darrel D-Walleer

D. D. Walker, Waste Processing Technology

$\frac{9 / 7 / 99}{\text { Date }}$

Design Check
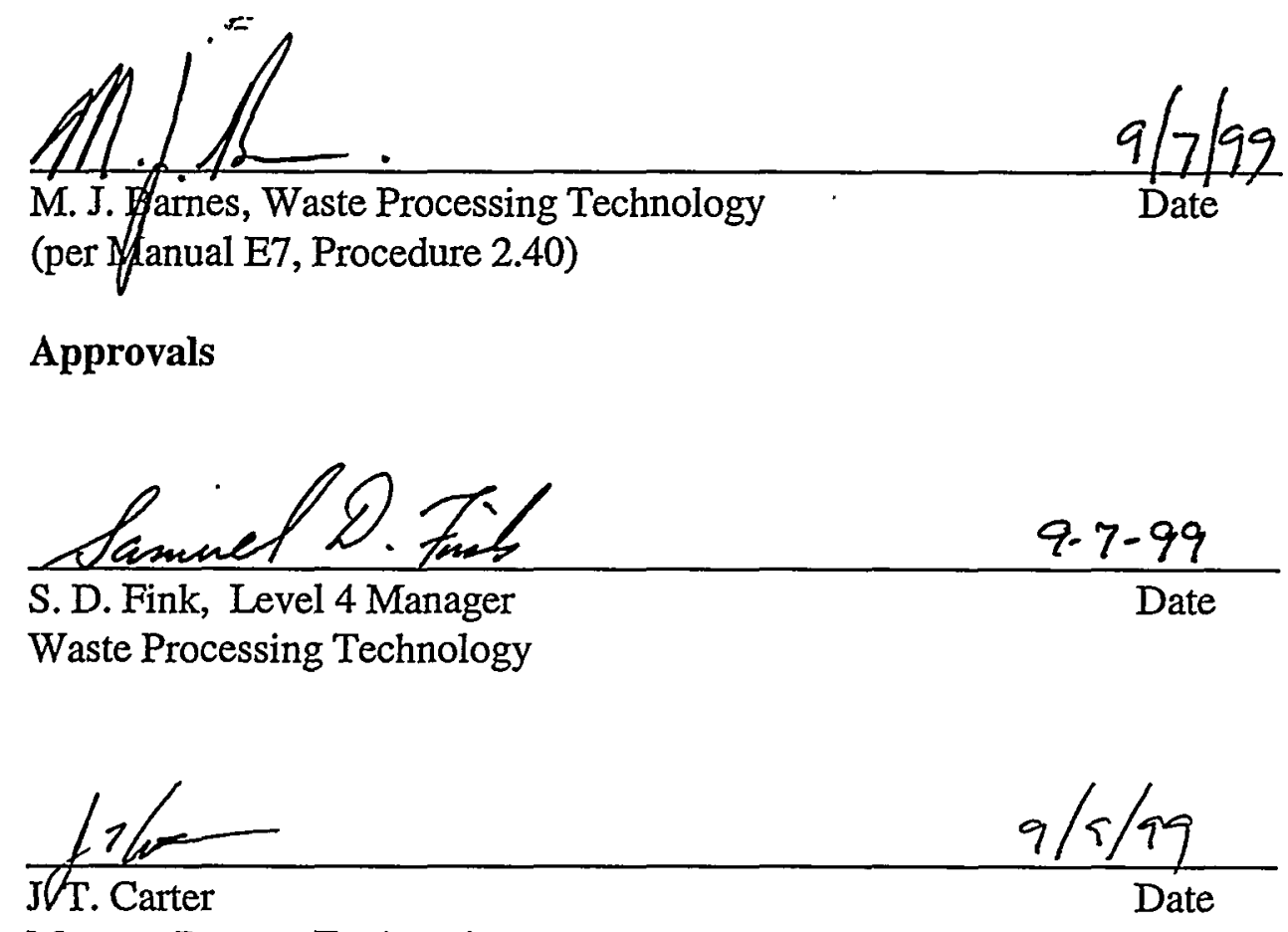

Manger, Process Engineering

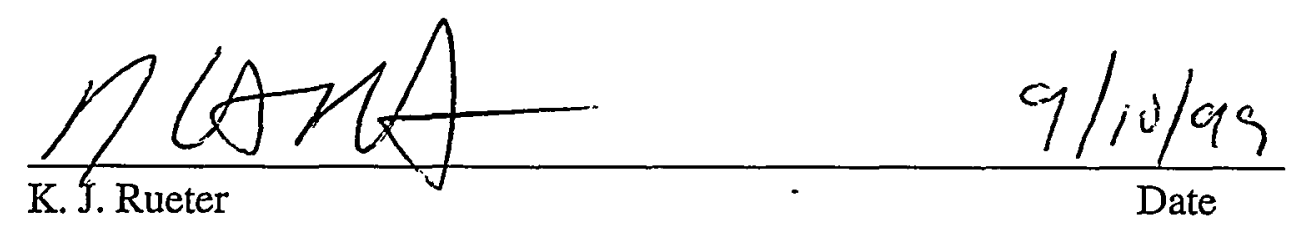

Director, Engineering

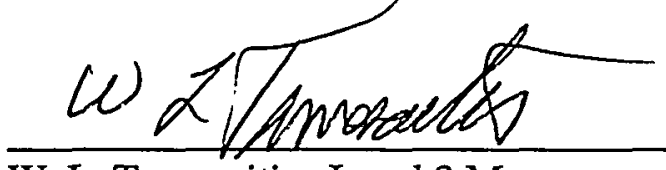

W. L. Tamosaitis, Level 3 Manager Waste Processing Technology 


\section{CONTENTS}

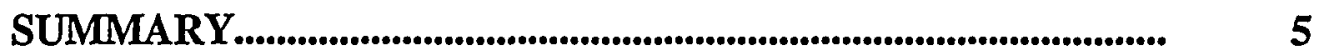

INTRODUCTION........................................................................... 5

TEST DESIGN AND RESULTS....................................................... 6

Oxygen Test.................................................................................... . 6

Catalyst Test............................................................................

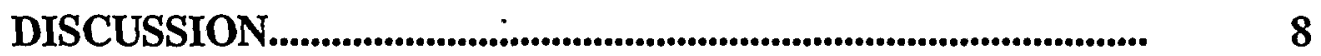

ACKNOWLEDGEMENTS.......................................................... 10

REFERENCES................................................................................... 10

APPENDIX A: Experimental........................................................ 12 


\section{LIST OF FIGURES}

$1 \quad$ Loss of Tetraphenylborate Under Oxygen or Nitrogen Atmosphere................................................................. 7

2 Effect of Catalyst on the Decomposition of Tetraphenylborate..... 9

3 Effect of Catalyst on the Concentration of 3PB............................ 9

4 Effect of Catalyst on the Concentration of 2PB.......................... 9

A-1 Experimental Apparatus for Oxygen Atmosphere Test.............. ' 13

$s$

\section{LIST OF TABLES}

I Summary of Test Conditions...................................................................... 6

II $\quad$ Comparison of Pd Catalyst Reaction Rates........................................... $\quad 10$

A-1 Composition of Simulated Waste Slurry........................................... 13

A-2 Catalyst Components in Simulant Slurries..................................... 14

A-3 Catalyst Forms and Sources........................................................................ 14

A-4 Analytical Results.................................................................... 16 


\title{
EFFECTS OF OXYGEN AND CATALYST ON TETRAPHENYLBORATE DECOMPOSITION RATE
}

\author{
BY D. D. WALKER
}

\section{SUMMARY}

Previous studies indicate that palladium catalyzes rapid decomposition of alkaline tetraphenylborate slurries. ${ }^{1-4}$ Oxygen inhibits the reaction at low temperature $\left(25^{\circ} \mathrm{C}\right)$, presumably by preventing activation of the catalyst. The present study investigated oxygen's inhibiting effectiveness at higher temperature $\left(45^{\circ} \mathrm{C}\right)$ and catalyst concentrations. Additional tests investigated the effect of metals (Pd or Pt) and form (soluble, or supported on $\mathrm{BaSO}_{4}$ or carbon) on the rate of reaction with soluble TPBThe following statements summarize the test results.

- Aeration using oxygen gas does not provide a robust method for preventing the decomposition of soluble TPB'.

- Although oxygen prevented decomposition at $25^{\circ} \mathrm{C}$ and $2.6 \mathrm{mg} \mathrm{Pd} / \mathrm{L}$, it did not significantly inhibit the decomposition at $45^{\circ} \mathrm{C}$ and $5.2 \mathrm{mg} \mathrm{Pd} / \mathrm{L}$ (double the nominal catalyst concentration).

- Despite many chemical similarities between platinum and palladium, neither soluble $\mathrm{Pt}(\mathrm{IV})$ nor $\mathrm{Pt}(0)$ supported on activated carbon catalyze the decomposition of tetraphenylborate ion.

- The support for the Pd catalyst affects the reaction rate.

$-\operatorname{Pd}(0)$ supported on activated carbon reacts at approximately half the rate of $\operatorname{Pd}(0)$ supported on $\mathrm{BaSO}_{4}$.

\section{INTRODUCTION}

Palladium catalyzes the decomposition of tetraphenylborate in alkaline solutions. ${ }^{1}$ Previous research suggests $\operatorname{Pd}(0)$ is the active form of the catalyst. ${ }^{2-4}$ At $25^{\circ} \mathrm{C}$ with oxygen present, the decomposition reaction of tetraphenylborate ion (TPB') initiates slowly or not at all. The results are consistent with a mechanism in which oxygen prevents the reduction of $\mathrm{Pd}$ (II) to $\mathrm{Pd}(0)$, thus inhibiting the catalyzed decomposition of TPB'. Depending on the effectiveness of oxygen in preventing catalyst activation, it might prove feasible to prevent decomposition of tetraphenylborate. Thus, researchers conducted an experiment at higher temperature $\left(45^{\circ} \mathrm{C}\right)$ and palladium concentration $(5.2$ $\mathrm{mg} / \mathrm{L}$ ). A tetraphenylborate slurry was stirred in the presence of oxygen to counteract the activation of the catalyst. Additional tests investigated the catalytic activity of platinum and the effect of the catalyst support. Previous reports conflicted on the catalytic activity 
of platinum. Researchers at Pacific Northwest National Laboratory ${ }^{5}$ (PNNL) found platinum supported on $\mathrm{TiO}_{2}, \mathrm{ZrO}_{2}$, or activated carbon caused degradation of - tetraphenylborate at $25^{\circ} \mathrm{C}$ and neutral pH. Researchers at the Savannah River Site found no degradation of TPB $^{-}$in the presence of $\mathrm{Pt}(\mathrm{IV})$ under alkaline conditions. ${ }^{3}$ This study

- included a test using platinum supported by activated carbon to investigate this discrepancy. In addition, testing investigated the effect of the support material $\left(\mathrm{BaSO}_{4}\right.$ and activated carbon) on the reactivity of palladium.

This work fulfills a request from P. L. Rutland, "TPB Solids Stability," Technical Task Request \#HLE-TTR-98039, Rev. 0, March 11, 1998. The work complies with the following plan: D. D. Walker, "Technical Task Plan for Solids Stability Studies of Tetraphenylborate Slurries - Additional Studies," WSRC-RP-98-00055, Rev.0, March 4, 1998.

\section{TEST DESIGN AND RESULTS}

Tests investigated the effect of oxygen on the reaction rate, and the effect of catalyst metal and substrate on catalyst activity. Table I provides a summary of the test conditions. Appendix A describes experimental details of the tests.

\section{Oxygen Test}

Previous test results indicated oxygen inhibits the palladium-catalyzed decomposition of soluble tetraphenylborate in alkaline solutions. ${ }^{2-4}$ At $25^{\circ} \mathrm{C}$ and $2.6 \mathrm{mg} \mathrm{Pd} / \mathrm{L}$ of slurry, no

\section{TABLE I. Summary Test Conditions}

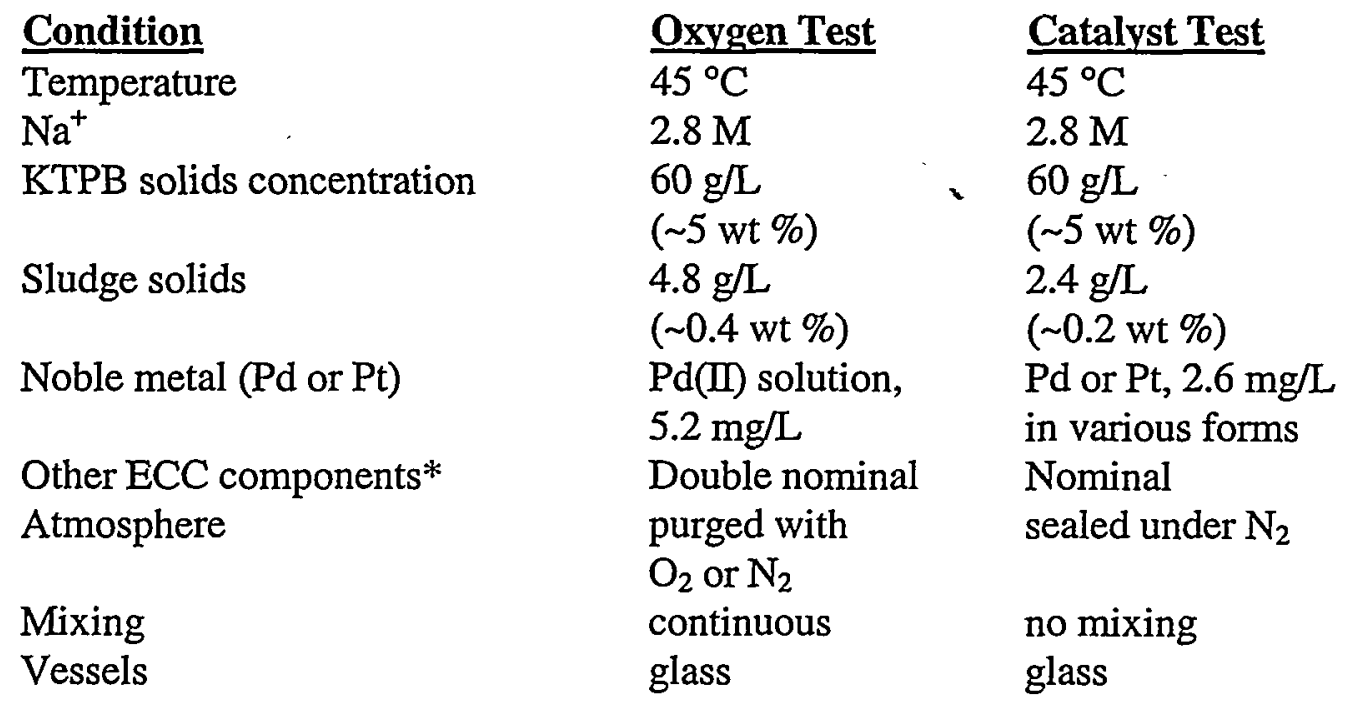

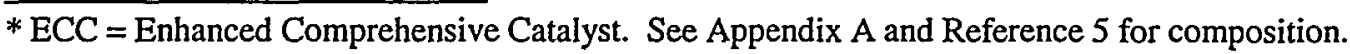


Figure 1. Loss of Tetraphenylborate Under Oxygen or Nitrogen Atmosphere (45 C).

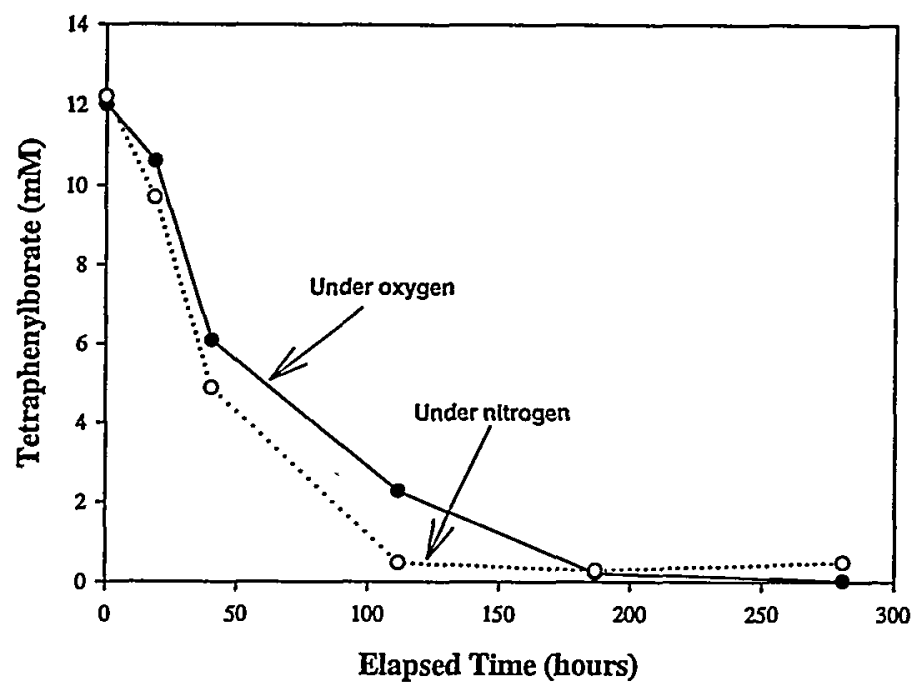

reaction occurred. However, at $45^{\circ} \mathrm{C}$ and $13 \mathrm{mg} \mathrm{Pd} / \mathrm{L}$ of slurry, the reaction proceeded in unstirred, sealed containers. Under these conditions (unstirred and sealed), local concentrations of oxygen may decrease sufficiently to allow catalyst activation. The current study explored the slurry reactivity under conditions more favorable for catalyst activation (i.e., at higher temperature and higher palladium concentration) to determine if an oxygen atmosphere can prevent catalyst activation. The test design included a simultaneous control test under nitrogen.

Both the nitrogen- and oxygen-purged slurries reacted at $45^{\circ} \mathrm{C}$. Figure 1 shows the decrease in soluble tetraphenylborate concentration during the test. Changes in the triphenylboron (3PB) and diphenylborinic acid (2PB) concentrations also confirm the loss of tetraphenylborate due to decomposition (Appendix A, Table A-4). As obvious from the figure, at elevated temperatures and these palladium concentrations, controlling the oxygen in the atmosphere above the slurry did not significantly slow the reaction.

\section{Catalyst Test}

The work also investigated the importance of the metal (Pd or Pt) and the form (soluble, or supported on $\mathrm{BaSO}_{4}$ or activated carbon). Platinum is a potential catalytic substitute for palladium based on their chemical similarity. In a single previous test at $45^{\circ} \mathrm{C}$, soluble platinum(IV) did not catalyze the decomposition of tetraphenylborate, presumably because it did not reduce to $\mathrm{Pt}(0){ }^{3}$ Researchers postulated that they could observe $\mathrm{Pt}$ catalysis if the experimental conditions avoided the apparently slow reduction step by starting with a reduced form of $\mathrm{Pt}$ (i.e., $\mathrm{Pt}(0)$ on a solid support). Thus, we repeated the 
test with soluble $\mathrm{Pt}(\mathrm{IV})$ and compared to a test using $\mathrm{Pt}(0)$ on activated carbon (abbreviated as $\mathrm{Pt}[\mathrm{C}]$ ). Another test examined the effect of the supporting phase for the $\mathrm{Pd}(0)$. $\mathrm{Pd}(0)$ supported on $\mathrm{BaSO}_{4}$ (abbreviated as $\mathrm{Pd}\left[\mathrm{BaSO}_{4}\right]$ ) catalyzed the tetraphenylborate decomposition at a slightly slower rate than soluble Pd(IV). Since $\mathrm{Pd}\left[\mathrm{BaSO}_{4}\right]$ proves relatively inactive compared to $\mathrm{Pd}[\mathrm{C}]$ in many systems, researchers postulated that $\mathrm{Pd}[\mathrm{C}]$ might serve as a more effective catalyst for the tetraphenylborate decomposition. We tested this hypothesis by comparing the reaction of $\mathrm{Pd}\left[\mathrm{BaSO}_{4}\right]$ to $\mathrm{Pd}[\mathrm{C}]$.

Neither of the two Pt catalysts reacted (Figure 2). A slight decrease in the TPBconcentration appears at the last sampling point ( 451 hours), but neither 3PB (Figure 3 ) nor 2PB (Figure 4) concentrations show a corresponding increase. The apparent decrease probably results from random analytical or sampling error. The lack of reactivity with platinum removes a possible explanation for the reactivity observed in radioactive waste tests. ${ }^{7}$ In those earlier tests, personnel suggested high reactivity of a small amount of $\mathrm{Pt}$ as a possible explanation for discrepancies between real waste (which may contain small amounts of $\mathrm{Pt}$ ) and the ECC simulant (which lacks $\mathrm{Pt}$ ).

With $\operatorname{Pd}(0)$, the substrate appears to slightly influence the decomposition rate. Figure 2 shows that both $\mathrm{Pd}\left[\mathrm{BaSO}_{4}\right]$ and $\mathrm{Pd}[\mathrm{C}]$ reacted. The observed rate of decomposition with $\mathrm{Pd}\left[\mathrm{BaSO}_{4}\right]$ proved approximately twice as rapid as with $\mathrm{Pd}[\mathrm{C}]$. Table II lists initial rates of tetraphenylborate decomposition from experiments using different $\mathrm{Pd}$ catalyst forms. Soluble Pd(II), however, provides a much faster reaction (see Table 2). The differences in reactivity may reflect differences in particle size or dispersion of the $\operatorname{Pd}(0)$.

\section{DISCUSSION}

The results of the oxygen atmosphere test indicate that stirring in the presence of oxygen gas does not provide a robust method for preventing the decomposition of soluble TPBAlthough oxygen prevented decomposition at $25^{\circ} \mathrm{C}$ and $2.6 \mathrm{mg} \mathrm{Pd} / \mathrm{L}$, it did not significantly inhibit the decomposition at $45^{\circ} \mathrm{C}$ and $5.2 \mathrm{mg} \mathrm{Pd} / \mathrm{L}$ (i.e., double the nominal catalyst concentration). Because of its limitations, this approach appears impractical for successful process application. The diffusion path length for oxygen in process equipment likely significantly exceeds that in the laboratory scale equipment. Hence, oxygenation to inhibit TPB decomposition will prove less effective than demonstrated in these tests. Oxygenation by sparging (i.e., direct injection of oxygen into the slurry) would prove ineffective because foaming will limit the sparging rate. Use of oxygen gas or air also raises flammability concerns that argue against this approach.

Despite many chemical similarities between platinum and palladium, neither soluble $\mathrm{Pt}(\mathrm{IV})$ nor $\mathrm{Pt}(0)$ supported on activated carbon catalyzed the decomposition of tetraphenylborate ion in simulated alkaline waste. Unpublished results from researchers at PNNL indicate platinum will catalyze TPB $^{-}$decomposition in neutral solution. ${ }^{5}$ The difference in $\mathrm{pH}$ between the two sets of tests likely causes the observed difference in reactivity. Platinum is not a fission product and only trace amounts -- much less than 
Figure 2. Effect of Catalyst on the Decomposition of Tetraphenylborate.

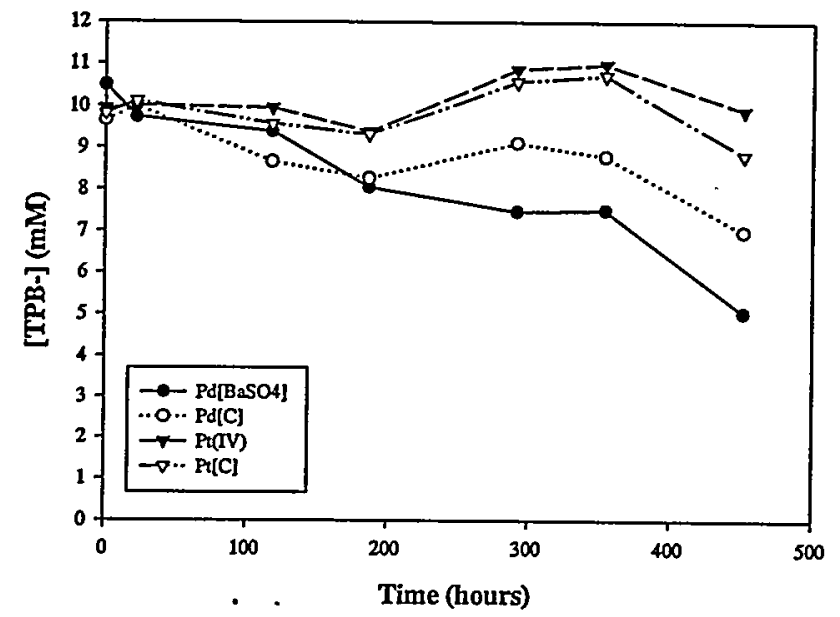

Figure 3. Effect of Catalyst on the Concentration of 3PB (45 deg.C)

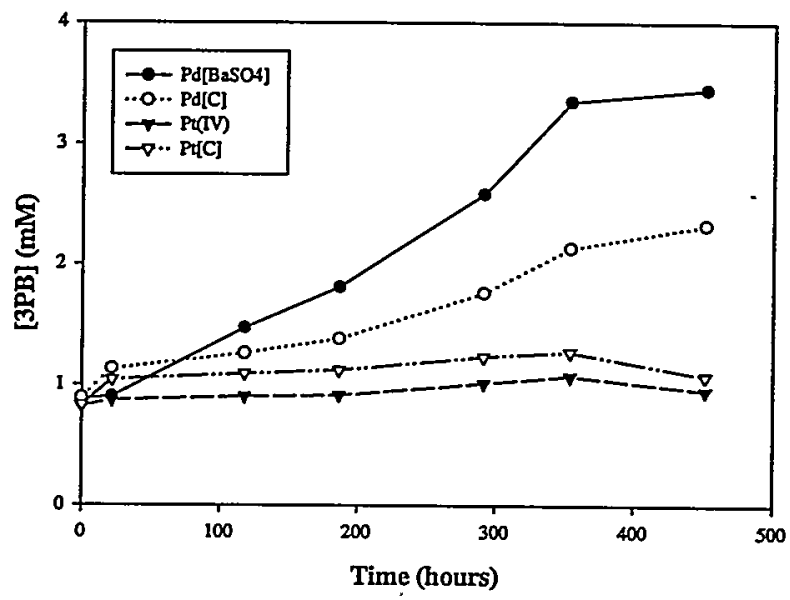

Figure 4. Effect of Catalyst on the Concentration of $2 \mathrm{~PB}$ (45 deg C).

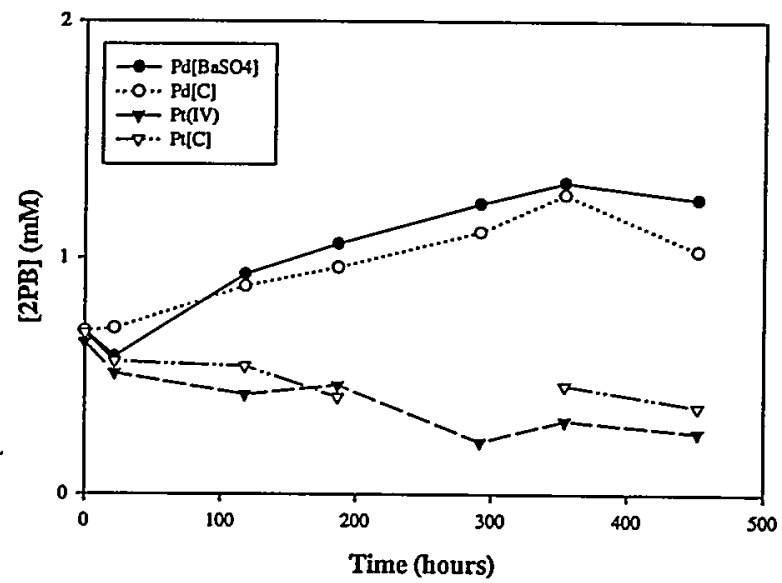




\section{TABLE II. Comparison of Pd Catalyst Reaction Rates}

\begin{tabular}{|c|c|c|c|c|}
\hline Catalyst form & Rate of loss of TPB ${ }^{-}$ & [Pd] & Temperat & re Reference \\
\hline & (mM/day) & $(\mathrm{mg} / \mathrm{L})$ & $\left.{ }^{\circ} \mathrm{C}\right)$ & \multirow{3}{*}{2} \\
\hline soluble $\mathrm{Pd}(\mathrm{II})$ & 0.6 & 11 & 25 & \\
\hline $\mathrm{Pd}\left[\mathrm{BaSO}_{4}\right]$ & 0.3 & 11 & 25 & \\
\hline $\mathrm{Pd}\left[\mathrm{BaSO}_{4}\right]$ & $0.25^{*}$ & 5.2 & 45 & This report. \\
\hline $\mathrm{Pd}[\mathrm{C}]$ & $0.11 *$ & 5.2 & 45 & This report. \\
\hline
\end{tabular}

*Rates calculated from the slope of graphs in Figure 2.

palladium - - exist in Savannah River Site radioactive waste. The low potential concentrations and lack of reactivity of platinum eliminates a possible explanation for the reactivity observed in radioactive waste tests. ${ }^{7}$ Previously, personnel speculated high specific reactivity of $\mathrm{Pt}$ as a possible explanation for discrepancies between reaction rates in SRS radioactive waste and the ECC simulant (which lacks Pt).

The test results indicate the substrate supporting the Pd catalyst affects the reaction rate. However, the variance appears relatively small (less than a factor of $\mathrm{x} 2$ ) between two very different supports $\left(\mathrm{BaSO}_{4}\right.$ and activated carbon). Both of the supported catalysts prove less reactive (per $\mathrm{mg}$ of $\mathrm{Pd}$ ) than systems starting with soluble $\mathrm{Pt}(\mathrm{IV})$ ), suggesting that the $\operatorname{Pd}(0)$ acts as the most effective catalyst when present as free $\operatorname{Pd}(0)$ particles or deposited directly on KTPB particles.

\section{ACKNOWLEDGEMENTS}

The author acknowledges the helpful discussions and suggestions from Mark J. Barnes, Samuel D. Fink, John R. Fowler, David T. Hobbs, Reid A. Peterson, and William R. Wilmarth in the design and interpretation of the experiments described in this report.

\section{REFERENCES}

1. M. J. Barnes and R. A. Peterson, "Sodium Tetraphenylborate Catalyst Identification: Phase B and C Statistical Design Studies (U)," WSRC-TR-97-0230, Rev.0, August 13, 1997.

2. D. D. Walker, "Effect of Palladium Form on Tetraphenylborate Decomposition Rate," WSRC-TR-98-00073, Rev.0, April 13, 1998.

3. D. D. Walker, "Low Temperature Decomposition Rates for Tetraphenylborate Ion," WSRC-TR-98-00342, Rev.0, October 2, 1998. 
4. M. J. Barnes and R. A. Peterson, "Excess Sodium Tetraphenylborate and Intermediates Decomposition Studies," WSRC-TR-98-00099, Rev.1, October 2, 1998.

5. Su, Yali, to S. D. Fink, "Preliminary Studies on the Degradation of Sodium Tetraphenylborate (TPB)," unpublished results, Environmental Molecular Sciences Laboratory, Pacific Northwest National Laboratory, Richland, WA, August 5, 1997.

6. M. J. Barnes, C. L. Crawford, and C. A. Nash, "Sodium Tetraphenylborate Catalyst Identification: Preliminary Studies Set 1 (U)," WSRC-TR-97-0060, Rev.0, March 6, 1997.

7. D. T. Hobbs, M. J. Barnes, R. A. Peterson, C. L. Crawford, and S. J. Emory, "Radioactive Testing Results in Support of the In-Tank Precipitation Facility," WSRCTR-98-00070, Rev.0, March 18, 1998. 


\title{
APPENDIX A
}

\author{
Experimental
}

\section{Preparation of Slurries}

Researchers prepared a simulated KTPB slurry (nominally 5 wt \% KTPB solids) with the composition shown in Table A-1. Researchers added $\sim 0.8 \mathrm{M}$ NaTPB solution to a $\sim 0.15$ $\mathrm{M} \mathrm{KNO}_{3}$ solution to ensure complete and rapid precipitation of KTPB, then added the soluble sodium salts to achieve $2.8 \mathrm{M} \mathrm{Na}^{+}$. All chemicals were reagent grade. NaTPB ( $99+\%$ purity) came from Aldrich Chemical Company.

\section{Oxygen vs. Nitrogen Atmosphere Test}

The apparátus for this test included glass reaction vessels $(9.0 \mathrm{~cm}$ diam $\times 10 \mathrm{~cm}$ tall) fitted with gas inlet and outlets (Figure A-1). House supply lines provided introgen or oxygen gas to purge the vapor space of the vessels. Low flow metering valves controlled the flow of gas. To preclude evaporation of the KTPB slurries, the gas streams were saturated with water using gas bubblers filled with deionized water. A water bath at $45.0 \pm 0.2^{\circ} \mathrm{C}$ provided temperature control for the bubblers and reaction vessels. Researchers weighed tetraphenylborate slurry $(131 \mathrm{~g}, 115 \mathrm{~mL})$, sludge $(3.18 \mathrm{~g}$ of $16.6 \mathrm{wt}$ $\%$ solids slurry), and monosodium titanate ( $3.42 \mathrm{~g}$ of $14.5 \mathrm{wt} \%$ solids slurry) into each vessel. Magnetic stir bars agitated the slurry as purge gas $(5 \mathrm{~mL} / \mathrm{min})$ flushed the vapor space. Bubbling the purge gas into the slurry was avoided because the slurry forms a persistent foam. The ECC metal and organic components (Table A-2) and soluble Pd(II) (5.2 $\mathrm{mg} \mathrm{Pd} / \mathrm{L}$ ) were then added to the slurries via syringe through septum-covered sampling ports in the tops of the vessels. Periodically, samples $(\sim 5 \mathrm{~mL})$ were removed via syringe, filtered using disposable acrylic copolymer syringe filters $(0.45$ micron nominal pore size, Gelman Sciences), and the filtrate analyzed for tetraphenylborate ion, triphenylboron, and diphenylborinic acid.

\section{Catalyst Test}

Researchers weighed slurry ( $141 \mathrm{~g}, 125 \mathrm{~mL}$ ), sludge (1.83 g of $16.6 \mathrm{wt} \%$ solids slurry), and monosodium titanate (1.84 $\mathrm{g}$ of $14.5 \mathrm{wt} \%$ solids slurry) into glass beakers. The remaining ECC metal and organic components (Table A-2) except benzene were added via syringe to the stirred slurry. To each portion of slurry was added one of the catalyst forms (Table A-3). Enough of the catalyst form was added to achieve $11 \mathrm{mg}$ Pd or Pt per liter of slurry. After stirring for one hour, approximately $130 \mathrm{~mL}$ of slurry were placed in $150-\mathrm{mL}$ glass serum bottles. Researchers capped the serum bottles with Teflon-lined serum caps, purged the vials with nitrogen, added the benzene (Table A-2), and placed the vials in the water bath at $45^{\circ} \mathrm{C}$. The remaining slurry in the beaker was used for the initial (zero time) sample. The vials were maintained at temperature, sealed, and unstirred for the duration of the test. Periodically, the vials were removed from the water 
FIGURE A-1. Experimental Apparatus for Oxygen Atmosphere Test

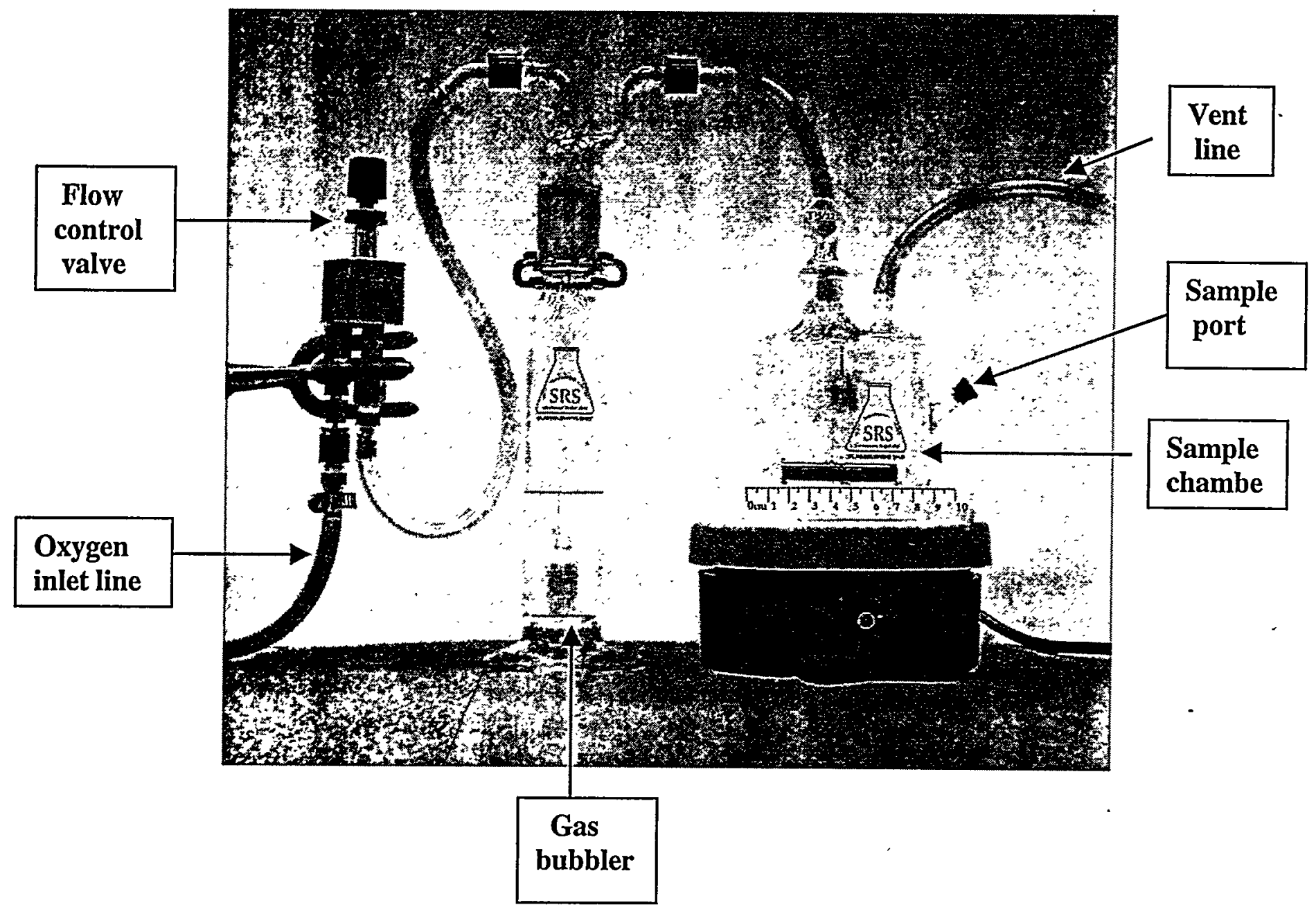

TABLE A-1 Composition of Simulated Waste Slurry (Excluding Catalyst Components)*

\begin{tabular}{lc} 
Component & Concentration (molar) \\
\cline { 1 - 2 } $\mathrm{Na}^{+}$ & 2.8 \\
$\mathrm{OH}$ & 0.84 \\
$\mathrm{NO}_{3}{ }^{-}$ & 1.06 \\
$\mathrm{NO}_{2}{ }^{-}$ & 0.39 \\
$\mathrm{AlO}_{2}^{-}$ & 0.17 \\
$\mathrm{CO}_{3}{ }^{2-}$ & 0.08 \\
$\mathrm{SO}_{4}{ }^{2-}$ & 0.07 \\
$\mathrm{Cl}^{-}$ & 0.013 \\
$\mathrm{~F}^{3}$ & 0.008 \\
$\mathrm{PO}_{4}{ }^{3-}$ & 0.005 \\
$\mathrm{TPB}$ & 0.002 \\
$\mathrm{KTPB}$ & $60 \mathrm{~g} /(-5 \mathrm{wt} \%)$
\end{tabular}

*See Table A-2 for catalyst components. 


\section{TABLE A-2. Catalyst Components in Simulant Slurries*}

Insoluble Components (wt \% of slurry)

$2.4 \mathrm{~g} / \mathrm{L}(\sim 0.2 \mathrm{wt} \%)$ sludge

$2.4 \mathrm{~g} / \mathrm{L}(\sim 0.2 \mathrm{wt} \%)$ monosodium titanate

Sludge composition (wt \% of dry sludge):

$\begin{array}{ll}\mathrm{Al} & 4.8 \\ \mathrm{Fe} & 28.8 \\ \mathrm{Mn} & 5.9 \\ \mathrm{Ru} & 0.23 \\ \mathrm{Rh} & 0.06 \\ \mathrm{Cr} & 0.2\end{array}$

$\begin{array}{ll}\mathrm{Cu} & = \\ \mathrm{Mg} & 0.1 \\ \mathrm{Ni} & 0.1 \\ \mathrm{~Pb} & 2.5 \\ \mathrm{Zn} & 0.3 \\ \mathrm{Zr} & 0.2 \\ & 2.5\end{array}$

Metal Additives (mg/L)

$\mathrm{Ca}$ (II) 12.2

Sr(I) $\quad 0.1$

$\mathrm{La}$ (III) 0.05

Ce(IV) $\quad 0.3$

$\mathrm{Cu}(\mathrm{II}) \quad 1.7$

$\mathrm{Ag}(\mathrm{I}) \quad 0.6$

$\mathrm{Zn}(\mathrm{II}) \quad 8.8$

$\begin{array}{ll}\mathrm{Ru} \text { (III) } & 0.8 \\ \mathrm{Co} \text { (II) } & 0.04 \\ \mathrm{Rh}(\mathrm{III}) & 0.2 \\ \mathrm{Sn} \text { (III) } & 2.1 \\ \mathrm{~Pb} \text { (II) } & 1.2 \\ \mathrm{As} \text { (IV) } & 0.04 \\ \mathrm{Se} \text { (VI) } & 1\end{array}$

Cd(II) $\quad 0.4$

$\mathrm{Hg}$ (II) $\quad 2.2$

Si(IV) 16

Cr(VI) 60

Mo(VD)12.

$\mathrm{Fe}(\mathrm{III}) \quad 2.6$

Organic Additives (mg/L)

$\begin{array}{ll}3 \mathrm{~PB} & 125 \\ 2 \mathrm{~PB} & 125 \\ \text { 1PB } & 125 \\ \text { Benzene } & 720 \\ \text { Biphenyl } & 150\end{array}$

$\begin{array}{llr}125 & \text { Diphenylmercury } & 150 \\ 125 & \text { Methanol } & 5 \\ 125 & \text { Isopropanol } & 50 \\ 720 & \text { Phenol } & 125 \\ 150 & & \end{array}$

\footnotetext{
* The amounts listed are nominal ECC catalyst concentrations (Ref.6). The oxygen atmosphere test used twice these concentrations. Pd (a component of the complete ECC catalyst system) is not listed because it was a variable in the tests. The nominal Pd concentration is $2.6 \mathrm{mg} / \mathrm{L}$.
}

TABLE A-3. Catalyst Forms and Sources

\begin{tabular}{|c|c|c|}
\hline Form & Source & Vendor \\
\hline $\mathrm{Pd}\left[\mathrm{BaSO}_{4}\right]$ & $\begin{array}{l}5 \mathrm{wt} \% \text { reduced } \mathrm{Pd} \text { on } \\
\text { powdered } \mathrm{BaSO}_{4}\end{array}$ & Alfa Aesar \\
\hline $\operatorname{Pd}[\mathrm{C}]$ & $\begin{array}{l}3 \mathrm{wt} \% \text { on activated carbon, } \\
50 \mathrm{wt} \% \text { water slurry }\end{array}$ & Alfa Aesar \\
\hline $\mathrm{Pt}(\mathrm{IV})$ solution & $\mathrm{Pt}(\mathrm{IV})$ chloride in $0.1 \mathrm{M} \mathrm{HCl}$ & High Purity Standards \\
\hline $\mathrm{Pt}[\mathrm{C}]$ & $\begin{array}{l}3 \mathrm{wt} \% \text { on activated carbon, } \\
50 \mathrm{wt} \% \text { water slurry }\end{array}$ & Alfa Aesar \\
\hline
\end{tabular}


bath, shaken briefly by hand, and sampled by syringe. During sampling, the vials were pressurized with nitrogen to prevent oxygen in-leakage.

\section{Analytical Results}

The samples were analyzed for tetraphenylborate ion, triphenylboron, and diphenylborinic acid. Table A-4 lists the analytical results.

\section{Analytical Methods}

The following analyses were performed by the Analytical Development Section of SRTC.

Tetraphenylborate, triphenylboron (3PB), and diphenylborinic acid (2PB) were measured by high performance liquid chromatography (HPLC) on a Hewlett Packard LC with a $2.1 \times 250 \mathrm{~mm}$ Dychrom Chemosorb 5-ODS-UH column using a $0.1 \%$ ammonium phosphate buffered acetonitrile-methanol-water eluent (La-mar-ka, Inc., Baton Rouge, LA). Manual L16.1, Procedure \#ADS-2655 describes the HPLC method. Sample and standard preparation for HPLC analyses is described in SRT-ADS-96-0438. 
WSRC-TR-99-00279, Rev. 0

Page 16 of 17

TABLE A-4. Analytical Results

\begin{tabular}{|c|c|c|c|c|c|c|}
\hline \multirow{2}{*}{$\begin{array}{c}\text { Elapsed } \\
\text { Time } \\
\text { (hours) }\end{array}$} & \multicolumn{3}{|c|}{ Oxygen } & \multicolumn{3}{|c|}{ Nitrogen } \\
\hline & NạTPB & 3PB & 2PB & NaTPB & 3PB & $2 \mathrm{~PB}$ \\
\hline 0.0 & 12.00 & 1.84 & 1.33 & 12.20 & 1.84 & 1.34 \\
\hline 18.6 & 10.60 & 2.37 & 1.46 & 9.70 & 4.01 & 1.28 \\
\hline 40.3 & 6.08 & 4.13 & 2.00 & 4.88 & 8.31 & 2.21 \\
\hline 111.5 & 2.28 & 3.61 & 5.90 & 0.48 & 6.92 & 7.83 \\
\hline 186.8 & 0.21 & 0.80 & 8.25 & 0.29 & 3.52 & 8.58 \\
\hline \multirow[t]{3}{*}{280.5} & $<.03$ & 0.14 & 6.60 & 0.49 & 3.14 & 5.66 \\
\hline & \multicolumn{3}{|c|}{$=\quad \operatorname{Pt}(\mathrm{IV})$ solution } & \multicolumn{3}{|c|}{$\mathrm{Pt}[\mathrm{C}]$} \\
\hline & NaTPB & 3PB & 2PB & NaTPB & $3 P B$ & 2PB \\
\hline 0.0 & 9.94 & 0.82 & 0.64 & 9.81 & 0.83 & 0.68 \\
\hline 21.9 & 10.01 & 0.87 & 0.51 & 10.12 & 1.04 & 0.56 \\
\hline 117.9 & 9.95 & 0.90 & 0.42 & 9.57 & 1.09 & 0.54 \\
\hline 186.5 & 9.38 & 0.91 . & 0.46 & 9.31 & 1.12 & 0.41 \\
\hline 291.5 & 10.86 & 1.01 & 0.22 & 10.57 & 1.23 & - \\
\hline 354.0 & 10.98 & 1.07 & 0.31 & 10.72 & 1.27 & 0.46 \\
\hline \multirow[t]{3}{*}{451.5} & 9.90 & 0.95 & 0.26 & 8.82 & 1.07 & 0.37 \\
\hline & \multicolumn{3}{|c|}{$\mathrm{Pd}[\mathrm{C}]$} & \multicolumn{3}{|c|}{$\mathrm{Pd}[\mathrm{BaSO} 4]$} \\
\hline & NaTPB & $3 \mathrm{~PB}$ & 2PB & NaTPB & 3PB & 2PB \\
\hline 0.0 & 9.65 & 0.89 & 0.69 & 10.49 & 0.88 & 0.69 \\
\hline 21.9 & 10.00 & 1.13 & 0.70 & 9.74 & 0.90 & 0.58 \\
\hline 117.9 & 8.65 & 1.26 & 0.88 & 9.38 & 1.47 & 0.93 \\
\hline 186.5 & 8.25 & 1.38 & 0.96 & 8.04 & 1.81 & 1.06 \\
\hline 291.5 & 9.10 & 1.76 & 1.11 & 7.46 & 2.58 & 1.23 \\
\hline 354.0 & 8.78 & 2.13 & 1.27 & 7.49 & 3.35 & 1.32 \\
\hline 451.5 & 6.98 & 2.32 & 1.03 & 5.03 & 3.45 & 1.25 \\
\hline
\end{tabular}


G. E. Abell, 704-3N

B. N. Attaway, 773-A

J. L. Barnes, 704-3N

M. J. Barnes, 773-A

S. B. Beck, 704-3N

J. T. Carter, 704-25S

G. L. Cauthen, 241-119H

W. C. Clark, 704-56H

N. R. Davis, 703-H

R. A. Dimenna, 773-42A

L. O. Dworjanyn, 779-2A

H. H. Elder, 704-S

S. D. Fink, 773-A

F. Fondeur, 773-62A

J. R. Fowler, 704-3N

J. C. Griffin, 773-A

T. Hang, 773-42A

D. C. Hannah, 703-46A

D. T. Hobbs, 773-A

E. W. Holtzscheiter, 773-A

P. R. Jackson, 703-46A

R. A. Jacobs, 704-3N

M. D. Johnson, 703-H

M. Howell, 704-196N

E. J. Kosiancic, 704-3N

L. F. Landon, 704-T

B. L. Lewis, 703-H

T. J. Lex, 703-H

P. E. Lowe, 773-41A

D. J. McCabe, 773-42A
J. W. McCollough, 703-H

M. S. Miller, 704-56H

T. M. Monahon, 703-H =

J. P. Morin, 703-H

E. T. Murphy, CCC\#3/10

C. A. Nash, 773-42A

L. M. Nelson, 773-43A

L. M. Papouchado, 773-A

P. K. Paul, 773-42A

R. A. Peterson, 773-A

S. F. Piccolo, 704-3N

M. R. Poirier, 676-T

M. J. Polochko, 773-A

J. Reynolds, 704-196N

K. J. Rueter, 704-3N

P. L. Rutland, 704-196N .

M. G. Schwenker, $703-46 \mathrm{~N}$

R. H. Spires, 703-H

W. E. Stevens, 773-A

P. C. Suggs, 704-196N

W. L. Tamosaitis, 773-A

G. A. Taylor, $704-196 \mathrm{~N}$

W. B. VanPelt, 676-1T

D. D. Walker, 773-A

R. T. Jones, 704-3N

W. R. Wilmarth, 773-42A

G. T. Wright, 773-A

J. E. Young, 773-A

TIM, 703-43A

WPTS Files, 773-A, c/o C. Canada, 773-A

ITP Files c/o Cathy Smalls, 241-147H 